American Journal of Animal and Veterinary Sciences 2 (1): 32-41, 2007

ISSN 1557-4555

(C) 2007 Science Publications

\title{
Evaluation of a DNA Vaccine for Immunocontraceptive Potential Against Zona Pellucida Glycoproteins in Cattle
}

\author{
${ }^{1}$ C. A. Foley, ${ }^{2}$ S.M. Boyle, ${ }^{1}$ R.E. Pearson and ${ }^{1}$ F.C. Gwazdauskas \\ ${ }^{1}$ Department of Dairy Science \\ ${ }^{2}$ Department of Biomedical Sciences \& Pathobiology, Virginia Polytechnic Institute and State University, \\ Blacksburg, VA 24061-0315
}

\begin{abstract}
Holstein cows were administered zona pellucida (ZP) DNA vaccine and used to determine the potential of recombinant rabbit ZP glycoproteins (rZP) as immunocontraceptive antigens. Zona pellucida proteins were purified and quantified. Cows were assigned to one of four treatment groups in which plasmids encoding rabbit ZP proteins were administered, i.d., using a gene gun (ZP55, $n=2$; $\mathrm{ZP75}, \mathrm{n}=2$; Hep55, $\mathrm{n}=2$; and Control, $\mathrm{n}=3$ ). Blood samples were taken before initial vaccination, once weekly for $5 \mathrm{wk}$ and at $148 \mathrm{wk}$ post-immunization. An ELISA was developed to assess anti-ZP titer levels in cow serum and ovarian function in cows was monitored using trans-rectal ultrasonography. Four of the six cows in ZP treatment groups developed antibody titer levels with similar linear responses over time. These cows also experienced reduced ovarian function as indicated by decreases in follicular and luteal activity. Estrous activity was observed in all cows and decreased in ZP treatment cows in comparison to Controls. Further research is needed to determine the relationship between ZP immunocontraception and ovarian function. Still, this study provides a basis for future researchers to use in developing a contraceptive vaccine for cattle.
\end{abstract}

Keywords: DNA vaccine, immunocontraception, zona pellucida, cattle

\section{INTRODUCTION}

Immunocontraception has the potential to be a vital asset to the cattle industry. The inhibition of fertilization via vaccination will minimize unfavorable pregnancies in feedlot systems, as well as decrease animal handling, human labor and possible health hazards that are characteristic of existing estrousregulating products. The transfection of Escherichia coli and expression of zona pellucida (ZP) glycoproteins from species such as the pig, rabbit, dog, or bonnet monkey is the process by which a vaccine is produced that will inhibit fertilization in other species. Studies show that immunocontraception using E. coliexpressed ZP glycoproteins is a method of pregnancy prevention in many species ${ }^{[1-5]}$.

The rabbit zona pellucida is composed of three glycoproteins: ZPA (R75), ZPB (R55) and ZPC (R45). The ZPB glycoprotein is generally chosen for immunization studies $^{[6]}$, because it has sperm receptor activity in rabbits. ZPB (R55) is also the structural homologue of porcine $\mathrm{ZP} 3 \alpha$ that has been documented as a possible target for immunocontraception ${ }^{[7,8]}$.
This study focused on rZP with the intent that it would be successful in generating antibody titer levels and eventually block the egg-sperm interaction in cattle. Two different rabbit ZP proteins were studied. For the purposes of this study, the targeted proteins were termed ZP55 and ZP75 due to their molecular weights of $55 \mathrm{kDa}$ and $75 \mathrm{kDa}$, respectively. Plasmid pRSET was used as the expression vector for ZP55 and ZP75 (Fig. 1).

The use of trans-rectal real-time ultrasonography as a research tool to investigate bovine reproduction is a technological advancement that has revolutionized the understanding of reproductive physiology in cattle ${ }^{[9]}$. Ultrasonography has been adopted throughout a variety of areas within bovine reproductive biology and has helped with the clarification of complex processes such as ovarian follicular dynamics, corpus luteum (CL) function and fetal development ${ }^{[10]}$. The objectives were to test the potential of recombinant rZP glycoproteins as immunocontraceptive antigens in the process of developing a vaccine to inhibit reproduction in cattle by monitoring ovarian function using trans-rectal ultrasonography and to develop an ELISA to assess

Corresponding Author: F. C. Gwazdauskas, Department of Dairy Science, Virginia Polytechnic Institute and State University, Blacksburg, VA 24061-0315, Fax: 540-231-5014 
anti-ZP titer levels from cows previously administered rZP DNA vaccines.

\section{MATERIALS AND METHODS}

Expression of ZP55 and ZP75 in recombinant $E$. coli: A single colony of recombinant $E$. coli BL21Star was inoculated into $5 \mathrm{~mL}$ Lennox Broth (LB) base (Gibco BRL, Life Technologies; Paisley, Scotland) containing ampicillin $\left(100 \mu \mathrm{g} \mathrm{mL}^{-1}\right)$. Two $\mathrm{mL}$ of grown culture was used to inoculate a flask containing $500 \mathrm{~mL}$ LB broth with ampicillin $\left(100 \mu \mathrm{g} \mathrm{mL}^{-1}\right)$. The E. coli was induced with $100 \mathrm{mM}$ concentration isopropyl-b-dgalactopyranoside (IPTG) protein expression agent (Novagen, EMD Biosciences, Inc., Madison, WI). Growth was continued at $37^{\circ} \mathrm{C}$ with shaking at $175 \mathrm{rpm}$ until an optical density of $600 \mathrm{~nm}$ was reached. The cells were extracted by centrifugation at $6,500 \mathrm{x} \mathrm{g}$ for $15 \mathrm{~min}$. The supernatant was stored at $4^{\circ} \mathrm{C}$ for future analysis. The cell pellet was weighed to determine the amount of cells present.

Inclusion body extraction: To lyse the recombinant $E$. coli BL21Star clones, BugBuster protein extraction reagent (Novagen) was added. The cell solutions were centrifuged at $12,000 \mathrm{x} \mathrm{g}$ for $15 \mathrm{~min}$ at $4^{\circ} \mathrm{C}$. The supernatant containing the soluble cell extract (SCE) was poured off and stored at $4^{\circ} \mathrm{C}$ for further analysis, while the cell pellet was re-suspended in BugBuster. This cell solution was then centrifuged at $10,000 \mathrm{x} g$ for $10 \mathrm{~min}$ and the supernatant containing the insoluble cell extract (ISE) was poured off and stored at $4^{\circ} \mathrm{C}$ for further analysis. Both the supernatant and the inclusion bodies were ultimately stored at $-20^{\circ} \mathrm{C}$.

SDS-PAGE analysis of recombinant $E$. coli cell culture: The SCE and ICE fractions resulting from the cell extraction of recombinant BL21Star E. coli were recovered from cold storage and prepared along with a control sample consisting of BL21Star + pRSET with no insert, for comparison purposes. The samples (ZP55, ZP75 and control) were combined with Laemmli buffer (Bio-Rad Laboratories; Hercules, CA) at a ratio of 1:1 and loaded into the wells of a $12 \%$ Tris- $\mathrm{HCl}$ Ready-Gel (Bio-Rad Laboratories) in $20 \mu \mathrm{L}$ aliquots. The Bio-Rad Protean mini-cell running apparatus was filled with $1 \mathrm{x}$ Reservoir buffer to perform the SDS-PAGE at $100 \mathrm{~V}$ for $90 \mathrm{~min}$. The resolving gels were rinsed in $\mathrm{dH}_{2} \mathrm{O}$ and equilibrated in Transblot buffer for $15 \mathrm{~min}$. One gel was stained with Coomassie blue stain reagent (Bio-Rad Laboratories) for 30 min while rocking at 4.5 medium speed. This gel was then rinsed with Coomassie destaining solution overnight while rocking at 4.5 medium speed. The stained gel was then photographed.
ZP 75 Plasmid Construct

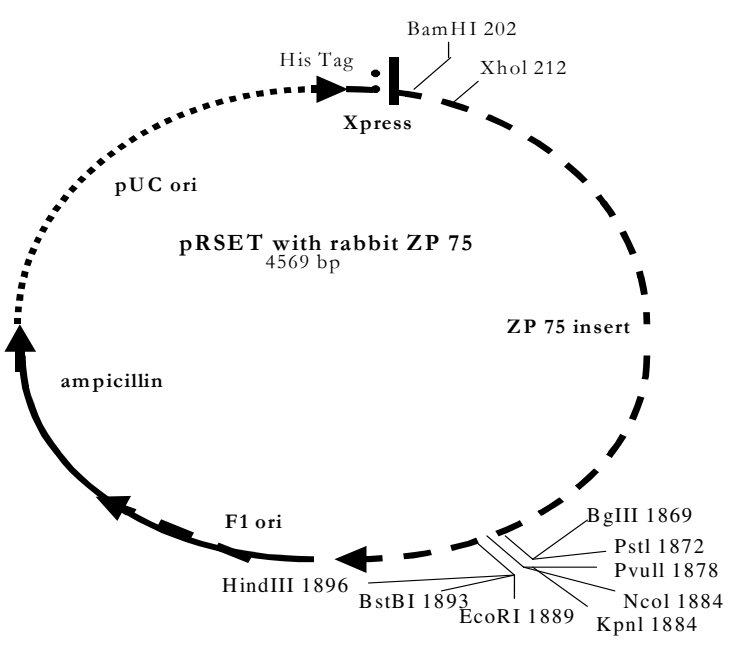

ZP 55 Plasmid Construct

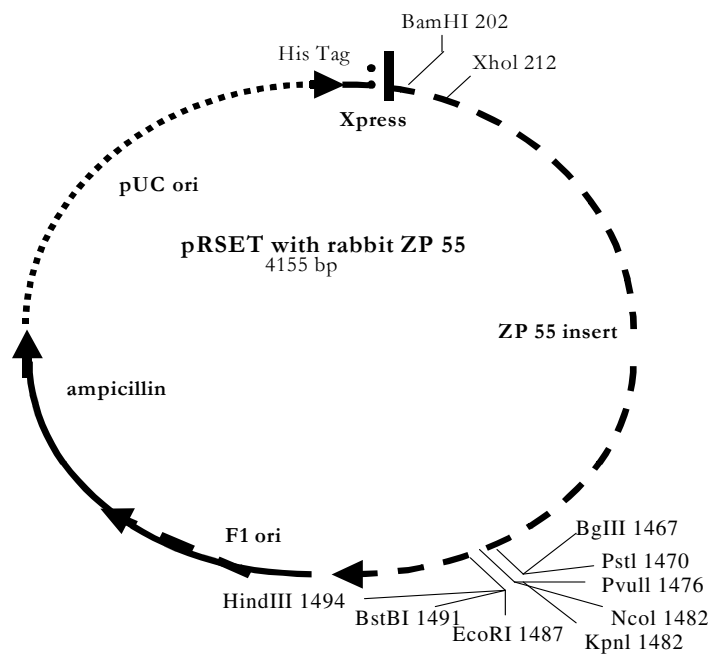

Fig. 1: Plasmid constructs used to immunize dairy cattle

Western blot analysis: After samples were separated by SDS-PAGE, the second resolving gel was equilibrated in Transblot buffer for $15 \mathrm{~min}$. Proteins were transferred to a nitrocellulose membrane that had been pre-soaked in Transblot buffer for $15 \mathrm{~min}$. The immunoblot was run for $35 \mathrm{~min}$ at $15 \mathrm{~V}$. The membrane was then stained temporarily with Ponceau $S$ stain reagent (Bio-Rad Laboratories) to visualize protein bands. The membrane was then cut into strips and notched with scissors for individual recognition. The strips were placed in $15 \mathrm{~mL}$ capped tubes, soaked in Blocking buffer and cooled overnight on a rocker at $4^{\circ} \mathrm{C}$ and 4.5 medium speed. The membrane strips were then washed twice for $5 \mathrm{~min}$ each time with $20 \mathrm{~mL} 1$ X TBS- 
Tween and then washed for 5 min with $15 \mathrm{~mL} 1 \mathrm{X}$ TBS. A $10 \mathrm{~mL}$ solution of His.Tag Monoclonal Mouse Antibody (Novagen) diluted 1:200 in Blocking buffer was then added to the strips and incubated overnight at $4^{\circ} \mathrm{C}$. The membrane strips were again washed twice for $5 \mathrm{~min}$ each time in $20 \mathrm{~mL} 1 \mathrm{X}$ TBS-Tween and then washed for $5 \mathrm{~min}$ with $15 \mathrm{~mL} 1 \mathrm{X}$ TBS. The strips were then incubated for $\sim 4 \mathrm{hr}$ at room temperature with $8 \mathrm{ml}$ Goat anti-Mouse IgG HRP Conjugate (Novagen) diluted 1:500 in TBS + blocking buffer. The membrane was washed five times for 5 min each time with $10 \mathrm{~mL}$ $1 \mathrm{X}$ TBS-Tween to ensure complete removal of unbound conjugate. The Western Blot substrate was prepared and used immediately to cover the membrane. Incubation for $\sim 15-20 \mathrm{~min}$ at room temperature allowed for adequate color development and the reaction was stopped by washing the membrane twice with $\mathrm{dH}_{2} \mathrm{O}$. Protein bands were observed ${ }^{[11]}$.

Inclusion body protein extraction: Inclusion bodies were resuspended in $10 \mathrm{~mL}$ BugBuster protein extraction reagent (Novagen) and $10 \mathrm{~mL}$ of a $300 \mu \mathrm{g}$ $\mathrm{mL}^{-1} \mathrm{rLysozyme}^{\mathrm{TM}}$ solution (Novagen) was added. The cells were incubated at room temperature for $5 \mathrm{~min}$. Sixty $\mathrm{mL}$ of $1: 10$ diluted BugBuster was then added and the solution was vortexed. The tube was then centrifuged at $5,000 \mathrm{x} \mathrm{g}$ for $15 \mathrm{~min}$ at $4^{\circ} \mathrm{C}$. The supernatant was discarded and the pellet was resuspended in $200 \mathrm{~mL}$ of 1:10 diluted BugBuster. The solution was centrifuged at $13,000 \mathrm{x} \mathrm{g}$ for $15 \mathrm{~min}$ at $4^{\circ} \mathrm{C}$. This supernatant was discarded and the pellet was resuspended in $20 \mathrm{~mL} 1 \mathrm{X}$ Binding buffer and incubated on ice for $1 \mathrm{hr}$. This inclusion body solution was centrifuged at $16,000 \mathrm{x} \mathrm{g}$ for $30 \mathrm{~min}$ at $4^{\circ} \mathrm{C}$. The supernatant was poured off and stored at $4^{\circ} \mathrm{C}$ for further analysis, while the pellet was discarded.

Affinity column chromatography of inclusion body protein: A His-Bind column (Invitrogen Life Technologies; Carlsbad, CA) was prepared according to the manufacturer's instructions for samples of ZP55, ZP75 and control samples. The ProBond ${ }^{\mathrm{TM}}$ Purification System kit (Invitrogen Life Technologies) was used with the procedure under denaturing conditions. ProBond ${ }^{\mathrm{TM}}$ resin was prepared by inverting and pouring $2 \mathrm{~mL}$ aliquots into each respective $10 \mathrm{~mL}$ purification column. Three $6 \mathrm{~mL}$ aliquots of Denaturing Binding buffer were allowed to flow through each column. The supernatant from the inclusion body purification was then added to the columns and the flow-through was collected in a $50 \mathrm{~mL}$ centrifuge vial. Two $4 \mathrm{~mL}$ aliquots of Denaturing Binding buffer were then administered to each column. Two $4 \mathrm{~mL}$ aliquots of Denaturing Wash buffer ( $\mathrm{pH}$ 6.0) and low imidazole concentration (20 $\mathrm{mM}$ ) were then allowed to flow through each column. Two $4 \mathrm{~mL}$ aliquots of Denaturing Wash buffer ( $\mathrm{pH}$ 5.3) were then added to each column and allowed to drip through. To elute the protein, $5 \mathrm{~mL}$ of Denaturing Elution buffer was added to each tube and allowed to drip through. Each eluate was collected in a $15 \mathrm{~mL}$ centrifuge vial. The flow-through from the inclusion body supernatant and the eluate solutions were stored at $4{ }^{\circ} \mathrm{C}$ for future analysis. A bicinchoninic acid (BCA) Protein Assay kit (Pierce Technologies; Rockford, IL) was used to determine the amount of protein present in the eluate.

Enzyme-linked immunosorbent Assay (ELISA) to detect ZP antibodies: This indirect assay was used to screen bovine antisera for specific ZP antibodies. To determine the optimal concentrations of antigen coating reagent (purified $\mathrm{ZP}$ ), secondary reagent (cow serum) and developing reagent (rabbit anti-bovine $\mathrm{IgG}$ Alkaline Phosphatase conjugate), a cris-cross serial dilution scheme was used.

Using a micropipette, $50 \mu \mathrm{L}$ of the coating reagent solutions were dispensed into the wells of four 96-well Maxisorp ELISA micro immuno-plates (Nalge Nunc International; Fischer Scientific International, Inc., Pittsburgh, PA), so that each plate was filled with one of four dilutions. Plates were incubated overnight at room temperature.

After incubation, the coated plates were rinsed with $\mathrm{dH}_{2} \mathrm{O}$ three times. The residual binding capacity of each plate was blocked with blocking buffer. Plates were incubated for $30 \mathrm{~min}$ at room temperature to allow for blocking. The plates were then washed $3 \mathrm{X}$ with $\mathrm{dH}_{2} \mathrm{O}$.

Five $12 \times 75-\mathrm{mm}$ test tubes were placed in a rack to prepare the secondary-reagent dilutions and $3 \mathrm{~mL}$ blocking buffer was added to the last 4 tubes. In tube 1 , a $4 \mathrm{~mL}$ solution of secondary reagent (ZP55 and ZP75 cow serum) at 1:100 in PBS was prepared. One $\mathrm{mL}$ of the tube 1 solution was then transferred to tube 2 and the contents were mixed by pipetting five times. This transfer and mixing was repeated for tubes 3, 4 and 5, so that the tubes then contained the secondary reactant at $1: 100,1: 400,1: 1,600,1: 6,400$ and 1:25,600 dilutions.

Fifty $\mu \mathrm{L}$ of the secondary reagent solutions were dispensed into the first five columns of all four coated plates. The most dilute solution was dispensed into column 5, while solutions of increasing concentrations were added successively into columns 4, 3, 2 and 1. The plates were then incubated for $2 \mathrm{hr}$ at room temperature. After incubation, the plates were then washed three times with $\mathrm{dH}_{2} \mathrm{O}$. Each well was then 
filled with Blocking buffer and then incubated for 10 min at room temperature. The plates were then washed $3 \mathrm{X}$ with $\mathrm{dH}_{2} \mathrm{O}$.

To prepare the developing-reagent dilutions, five $17 \times 100-\mathrm{mm}$ test tubes were placed in a rack and $3 \mathrm{~mL}$ Blocking buffer was added to the last four tubes. In tube 1, a $6 \mathrm{~mL}$ solution of developing reagent (rabbit anti-bovine $\operatorname{IgG}$ alkaline phosphatase conjugate) was prepared at 1:500 dilution in Blocking buffer. Three $\mathrm{mL}$ of the tube 1 solution was then transferred into tube 2 and mixed by pipetting $5 \mathrm{X}$. This transfer and mixing procedure was repeated for tubes 3,4 and 5 , so the tubes contained the developing reagent at 1:500, $1: 1,000,1: 2,000,1: 4,000$ and 1:8,000 dilutions. Fifty $\mu \mathrm{L}$ of the developing reagent solutions were dispensed into the wells of rows 2 to 6 of each plate, dispensing the most dilute solution into row 6 and solutions of increasing concentration successively into rows 5, 4, 3 and 2. The plates were then incubated for $2 \mathrm{hr}$ at room temperature.

After incubation, the plates were washed $3 \mathrm{X}$ with $\mathrm{dH}_{2} \mathrm{O}$. Each well was then filled with Blocking buffer, the plates were vortexed to remove any reagent remaining in the corners of the wells and then incubated for $10 \mathrm{~min}$ at room temperature. The plates were then washed $3 \mathrm{X}$ with $\mathrm{dH}_{2} \mathrm{O}$.

An alkaline phosphatase substrate kit was used to measure hydrolysis and detect bound antibodies (BioRad Laboratories). The substrate was prepared by mixing together $1 \mathrm{~mL}$ of $5 \mathrm{x}$ diethanolamine buffer and $4 \mathrm{~mL}$ of $\mathrm{dH}_{2} \mathrm{O}$ for each p-Nitrophenylphosphate (NPP) tablet. The tablets were completely dissolved and the solution was observed as a pale yellow color. Seventyfive $\mu \mathrm{L}$ of NPP substrate solution was added to each well and the plates were incubated for $1 \mathrm{hr}$ at room temperature. Hydrolysis was monitored qualitatively by visual inspection and then quantitatively using a $\mu$ Quant Spectrophotometer plate reader (BIO-TEK Instruments, Inc., Winooski, VT). The optical densities of each sample were measured at $405 \mathrm{~nm}$ using the alkaline phosphatase protocol of KCJunior computer software (BIO-TEK Instruments, Inc.).

A second ELISA was conducted with the known desirable concentration of developing reagent from the first assay (1:8,000 rabbit anti-bovine alkaline phosphatase conjugate in Blocking buffer), in order to determine titer levels of antibodies present in the diluted amounts of cow serum. The assay was conducted under the same conditions with the same reagents and solutions.

Whole cell adsorption of bacterial antibodies from serum: An adsorption technique was used to eliminate any background reaction that may have been caused by the presence of E. coli. The original E. coli bacterial strain with the ZP55 plasmid was grown overnight in $50 \mathrm{~mL}$ of LB broth (Gibco BRL, Life Technologies) with ampicillin $\left(100 \mu \mathrm{g} \mathrm{mL}^{-1}\right)$. The bacteria cells were harvested via centrifugation at $5,000 \mathrm{x} \mathrm{g}$ in a refrigerated centrifuge for $15 \mathrm{~min}$ at $4^{\circ} \mathrm{C}$. The bacteria were then resuspended in $5 \mathrm{~mL}$ PBS and incubated in $60 \%$ methanol for $1 \mathrm{hr}$ to kill the E. coli. The killed strain was harvested via centrifugation at 5,000 $\mathrm{x} \mathrm{g}$ for $15 \mathrm{~min}$ at $4^{\circ} \mathrm{C}$ and resuspended in $5 \mathrm{~mL}$ PBS.

Serum from a single cow was chosen based on previous ELISA results and overall trends with respect to antibody titer levels over time. This serum (cow previously administered ZP55) was diluted 1:100 in PBS-killed cells solution. In this dilution $10 \mu \mathrm{L}$ of serum was added to $990 \mu \mathrm{L}$ of killed cells and the solution was incubated in a closed, sterile tube overnight at $4^{\circ} \mathrm{C}$ to adsorb the serum. The killed cells with adsorbed antibodies were removed via centrifugation at $5,000 \mathrm{x} \mathrm{g}$ for $15 \mathrm{~min}$ at $4^{\circ} \mathrm{C}$. The supernatant as adsorbed serum was removed and stored at $4^{\circ} \mathrm{C}$ for future ELISA analysis.

A third ELISA was conducted to observe the differences between $E$. coli adsorbed cow serum and unadsorbed serum. The same protocol was followed as described earlier with only one plate being coated with $1.25 \mu \mathrm{g} \mathrm{mL} \mathrm{m}^{-1}$ coating reagent ZP55 protein. The adsorbed cow serum from the previous reaction was prepared as the secondary reagent. Along with the adsorbed cow serum, unadsorbed cow serum from the same animal was also diluted and dispensed onto the plate for comparison purposes. The developing reagent was prepared at a uniform dilution of 1:8,000 (rabbit anti-bovine $\operatorname{IgG}$ alkaline phosphatase conjugate in Blocking buffer) and dispensed onto the plate in $50 \mu \mathrm{L}$ aliquots.

Animals and treatments: Non-lactating Holstein cows $(n=9)$ were used to evaluate the effects of administered ZP DNA vaccine on ovarian follicle and CL dynamics. The animals were maintained under identical housing, nutritional and management conditions throughout the experimental period at the Dairy Cattle facility of Virginia Tech.

In June 2001, 6 of the 9 cows were immunized with naked DNA. To examine the immune response, different plasmids encoding rabbit ZP proteins (Fig. 1) were administered, i.d., using a gene gun ${ }^{[12]}$. The respective plasmids included ZP55 (rZP55), ZP75 (rZP75) and Hep55 (Hepatitis B and rZP55). Each dosage consisted of $0.1 \mathrm{mg} \mathrm{DNA} / \mathrm{cow}$. Injection protocols were approved by the University Animal Care Committee. 
The ultrasound study began 26 mo after the initial immunization with ZP. The original cows were subjected to trans-rectal ultrasound on a weekly basis with the intent of using the ultrasound data as an indication of ovarian function over time.

Ultrasound equipment and procedure: An ALOKA SSD-500V ultrasound (Corometrics Medical Systems, Inc., Wallingford, CT) was used weekly to observe the follicular dynamics and presence of CL on the ovaries. Follicle and CL size were recorder in $\mathrm{mm}$. Cows were subjected to ultrasound 47 times over the course of a 13 mo period. Throughout the study all cows showed signs of follicular and luteal activity on their ovaries and differences in follicular wave patterns in which ovarian structures developed and regressed in a cyclic fashion were noted. To observe the possible effects of ZP immunization on ovarian dynamics and function, the ultrasound dates were broken down into 3-wk periods to mimic the usual 21-d estrous cycle of the cow. A total of 16 cycles were accounted for and of those cycles, ones in which CL were present were considered to be viable cycles in which follicular waves occurred $^{[10]}$.

Blood sampling techniques: A $20 \mathrm{~mL}$ blood sample was collected via jugular venipuncture from each cow at weekly intervals beginning at the primary immunization until $5 \mathrm{wk}$ post primary immunization. Another blood sample was collected via jugular venipuncture on at 148 wk post-immunization. Serum was harvested from all blood samples via centrifugation at $2,000 \mathrm{x} \mathrm{g}$ for $20 \mathrm{~min}$ and stored at $-20^{\circ} \mathrm{C}$ for future antibody titer quantification.

Statistical analysis: The main effects of serum dilutions, week and their interaction were tested using the GLM portion of SAS (SAS Institute, Inc.; Cary, $\mathrm{NC}$; Version 8.0). The dependent variable was optical density (O.D. $405 \mathrm{~nm}$ ), which represented respective titer levels. Serum dilutions were 1:100, 1:400, 1:1,600, $1: 6,400$, or $1: 25,600$ and weeks were $1,2,3,4,5$ and 148. Orthogonal polynomial contrasts were used to test for linear and quadratic trends in serum dilutions by week. Animal models included treatment, ultrasound date and cow within treatment. Dependent variables were follicle number and CL size ( $\mathrm{mm})$. Treatments were Control, Hep55, ZP55 and ZP75. Results are presented as least squares means \pm SEM. Differences were considered significant at $P<0.05$.

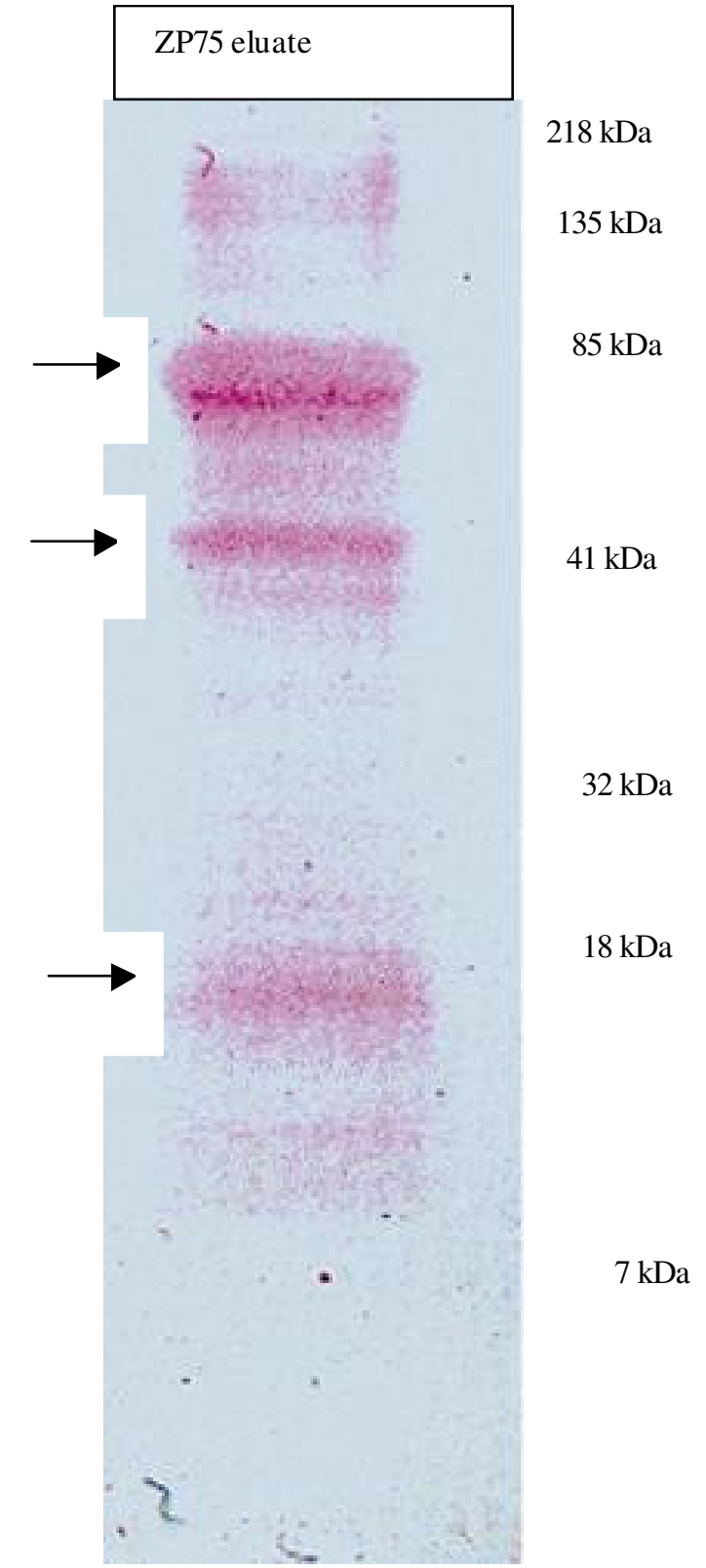

Fig. 2: Western immunoblot of ZP75 purified eluate from affinity purification column. Molecular weight markers are at specified areas. Top arrow indicates major protein band at 75 $\mathrm{kDa}$, and lower arrows indicate accessory protein bands at 45 $\mathrm{kDa}$ and $15 \mathrm{kDa}$

\section{RESULTS}

Purification of recombinant $\mathrm{ZP}$ proteins: Growth of E. coli and induction of ZP proteins with IPTG allowed for expression of ZP55 and ZP75 proteins on SDSPAGE gel. The bands were evident at the $55 \mathrm{kDa}$ and $75 \mathrm{kDa}$ molecular weight markers when the whole cell lysates were subjected to SDS-PAGE (data not shown). 


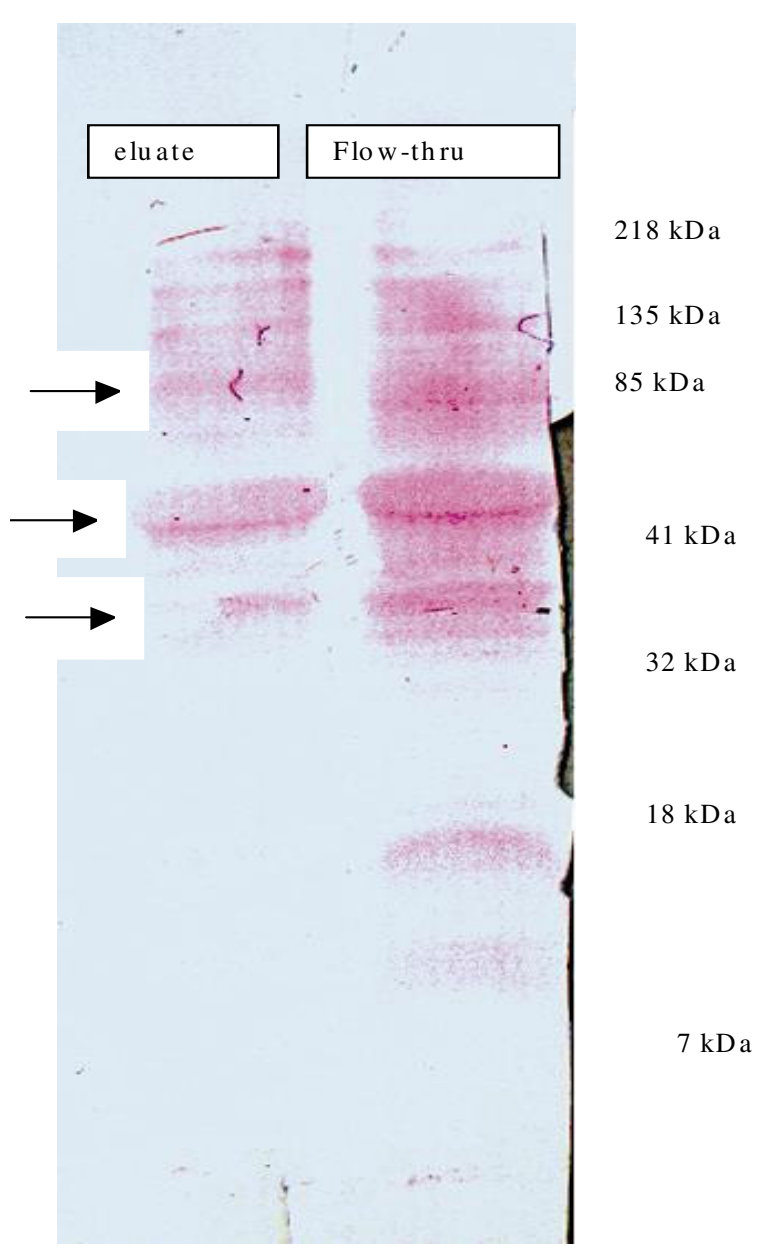

Fig. 3: Western immunoblot of ZP55 affinity column flow-thru, and ZP55 purified eluate. Molecular weight markers are at specified areas. Center arrow indicates major protein band at $55 \mathrm{kDa}$ and other arrows indicate accessory protein bands at $85 \mathrm{kDa}$ and $38 \mathrm{kDa}$

Reactivity of purified ZP proteins with antibodies in western blot: Upon purification of whole cell lysates via affinity column chromatography, the collected products were subjected to SDS-PAGE and Western blotting (Fig. 2 and 3). A Western blot of purified ZP75 produced protein bands at $75 \mathrm{kDa}$ for the eluate fraction, as well as faint bands at $\sim 45 \mathrm{kDa}$ and $15 \mathrm{kDa}$ (Fig. 2). A Western blot of purified ZP55 produced major protein bands at $55 \mathrm{kDa}$ for both the flow-thru and the eluate fractions and also showed faint bands at $\sim 38 \mathrm{kDa}$ and $85 \mathrm{kDa}$ (Fig. 3).

Reactivity of ZP proteins in bovine serum with rabbit anti-bovine IgG: It was determined that an

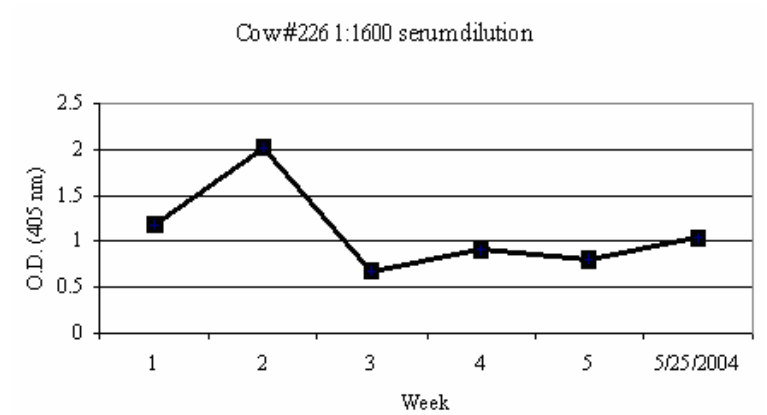

Fig. 4: Representative levels of anti-ZP antibodies present in cow serum subjected to ELISA using 1:1,600 serum diluted in blocking buffer. Cow 226 (ZP75). Week 1 represents serum taken prior to DNA gene gun injection, while wk 2 to 5 represent the period following administration of DNA, and 5/25/04

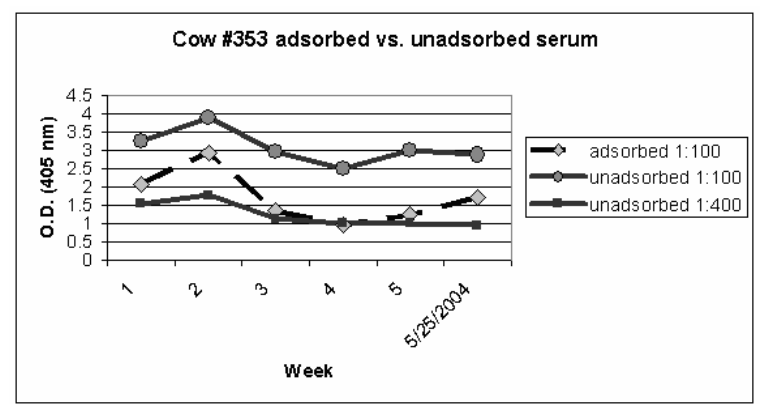

Fig. 5: Comparison between 1:100 unadsorbed bovine serum and 1:100 adsorbed serum without E.coli background. Serum from cow \#353 (ZP ZP55) was used. Unadsorbed 1:400 serum is plotted as an additional comparison. 1:400 serum dilution was significantly linear and quadratic $(P=0.05)$

adequate reaction was observed by using $1.25 \mu \mathrm{g} \mathrm{mL} \mathrm{L}^{-1}$ coating antigen and 1:8,000 developing reagent in blocking buffer. These concentrations were used in the following ELISA experiments along with the diluted bovine serum $(1: 100,1: 400,1: 1,600,1: 6,400$ and $1: 25,600)$ in Blocking buffer.

The subsequent ELISA was conducted to measure titer levels of antibodies generated to $\mathrm{ZP}$ in the bovine serum and to observe their fluctuation over time (Fig. 4). Statistical analysis showed that the 1:100 serum dilution result was not linear $(\mathrm{P}=0.66)$ or quadratic $(\mathrm{P}=0.48)$. But, the O.D. readings for the 1:400, 1:1,600, $1: 6,400$ and $1: 25,600$ serum dilutions were within range. The 1:1,600 and 1:6,400 dilutions were significantly quadratic $(\mathrm{P}<0.03, \mathrm{P}<0.04)$ with respect to week. Cows 353 (ZP55), 259 (Hep55), 226 (ZP75) and 
437 (ZP75) had increases in O.D. readings the week after DNA injection. Cows 441 (ZP55) and 284 (Hep55) did not have higher O.D. readings after injection.

An ELISA was conducted to compare unadsorbed cow serum with adsorbed serum without $E$. coli background. The adsorbed 1:100 cow serum was significantly different than the unadsorbed 1:100 cow serum O.D. values ( $\mathrm{P}=0.04$; Fig. 5).

Reproductive activity: Two control cows were added to the group of 7 existing animals in order to compensate for the loss of cow 194. At $\sim 12$ wk after the first ultrasound date, cow 259 died from causes unrelated to the project, which left a total of 8 cows for the remainder of the study.

Of the 8 cows, the 3 control cows showed a constant level of 12-13 cycles in which CL were present. Cow 441 (ZP55) and cow 226 (ZP75) showed similar responses to control cows, both having 12 cycles in which CL were present. Cow 284 (Hep55), cow 353 (ZP55) and cow 437 (ZP75) all had lower instances of cycles with CL present with 8,6 and 8 cycles, respectively (Fig. 6).

The number of follicles on the left ovary was significantly affected by treatment $(P<0.01)$, ultrasound date $(P<0.01$; data not shown $)$ and cow within treatment group $(P<0.02$; data not shown). Within the treatment groups, significant differences occurred between the Hep55 having fewer follicles $(3.12 \pm 0.51)$ than Control $(4.85 \pm 0.21)$, ZP55 $(5.10 \pm 0.25)$ and ZP75 $(4.39 \pm 0.25)$ groups $(P<0.05)$. The number of left ovarian follicles was less for ZP55 than ZP75 $(P<0.05)$. Cow 284 (Hep55) had significantly lower numbers than Control cows $351(P<0.01)$ and $748(P<0.01)$ and cow 441 (ZP55; $P<0.05$ ). Cow 353 (ZP55) had significantly more left ovarian follicles than cow $716(P<0.01)$ and cow 284 (Hep55) $(P<0.01)$. Cow 226 (ZP75) had significantly lower left ovarian follicles than cow 351 $(P<0.05)$ and cow 437 (ZP75) had fewer left ovarian follicles than cow $351(P<0.02)$ and cow 353 (ZP55) $(P<0.02)$.

The total number of ovarian follicles was calculated for each cow on each ultrasound date and used to measure overall ovarian function. The total number of follicles for each cow was significantly affected by ultrasound date $(P<0.01)$ and cow within treatment effect $(P<0.01)$. Cow 284 (Hep55; $8.36 \pm$ $0.52)$ had significantly less follicle numbers than cow $351(10.37 \pm 0.53 ; P<0.01)$, cow $748(10.18 \pm 0.53$; $P<0.02)$ and cow $226(\mathrm{ZP75} ; 10.36 \pm 0.52 ; P<0.01)$. Cow 353 (ZP55; $10.83 \pm 0.52$ ) had significantly more total follicular numbers than cows $716(9.14 \pm 0.54)$,

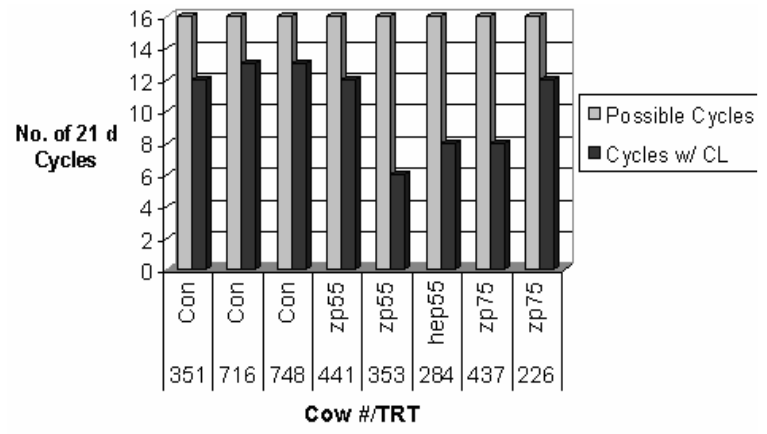

(a)

(b)

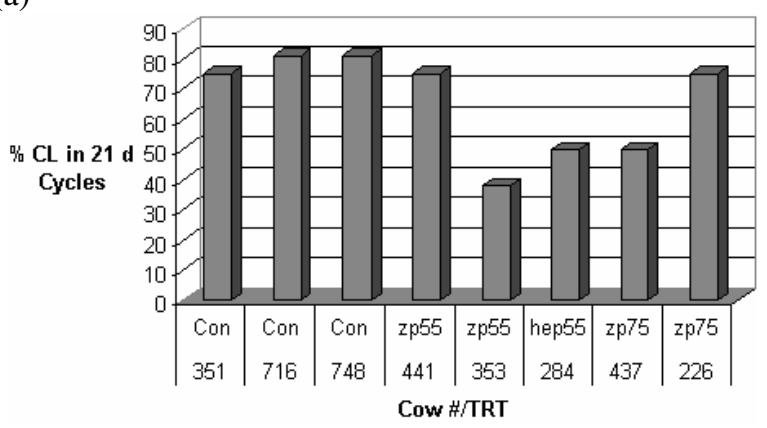

Fig. 6: Overall number of $21 \mathrm{~d}$ cycles and cycles in which corpora lutea (CL) were present expressed as (a) number of cycles with CL, and (b) percentage of cycles in which CL were present. Data are presented with respect to individual cow number and treatment (TRT) group (ZP55, ZP75, and Control (Con))

$284($ Hep55; $8.36 \pm 0.52), 441($ ZP55; $9.33 \pm 0.53)$ and 437 (ZP75; $8.03 \pm 0.52 ; P<0.05$, respectively). Cow 437 (ZP75) had fewer total follicles than cows 351, 748 and 226 (ZP75) $(P<0.01$, respectively).

\section{DISCUSSION}

Attempts at purification focused on protein extraction from the inclusion bodies, indicating that $\mathrm{ZP}$ aggregates when it is over-expressed, rather than remaining in a soluble form. SDS-PAGE analysis of both ZP55 and ZP75 recombinant BL21Star showed bands of protein expression. Western blots of ZP55 and ZP75 eluates showed bands at molecular weights differing from the desired $55 \mathrm{kDa}$ and $75 \mathrm{kDa}$ markers (Fig. 2 and 3). This indicates that perhaps a different technique of purification is necessary instead of the His-Bind affinity column chromatography scheme. It is possible that the $\mathrm{Ni}^{2+}$ resin in the columns did not bind only the ZP when the initial flow-thru was passed through the columns ${ }^{[13]}$. 
Mate et $a .^{[13]}$ sought to express and classify the three ZP proteins of the brushtail opossum (PZP) and had results similar to our findings. In addition to the known $54 \mathrm{kDa}$ rPZP1, $32 \mathrm{kDa}$ rPZP2-N, $39 \mathrm{kDa}$ rPZP2-C and $40 \mathrm{kDa}$ rPZP3 polyhistidine tag fusion proteins, a few minor protein bands were present after purification with Ni-NTA resin that were reactive with anti-ZP antibodies. The researchers contributed these bands to either degraded $\mathrm{ZP}$ products, or the premature termination of translation products. As the unknown bands in the present study were generally of lower molecular weight, they could similarly represent degraded ZP fragments that were able to traverse the gel and react with anti-ZP antibodies.

The results from the ELISA provided evidence of $\mathrm{ZP}$ antibodies in the bovine serum taken from the experimental cows that had been administered DNA encoding ZP with a gene gun. Four of the six cows showed similar trends with respect to titer levels over time. Those cows were 353 (ZP55), 259 (Hep55), 226 (ZP75) and 437 (ZP75). After the initial blood sample and DNA injection at $1 \mathrm{wk}$, a spike in titer level was observed at $2 \mathrm{wk}$. The levels then generally decreased slightly, following a quadratic pattern. These four cows reacted similarly with respect to titer level over time, showing that ZP antibodies were developed to the DNA vaccine injection. It also raises speculation that ZP75 was the most reactive as both cows in this treatment group responded in a similar fashion. Fayrer-Hosken $e t$ $a l .^{[14]}$ sought to classify the potential of a $\mathrm{pZP}$ vaccine for the African elephant and describe results with respect to titer levels similar as seen in the present study. They found that antibody titer levels to the initial immunization rose immediately following vaccination. But, these increases were short-lived and declined over the following weeks to where they were almost completely diminished by $100 \mathrm{~d}$.

In an effort to remove any possible background effects of $E$. coli, a sample of cow serum was subjected to an adsorption scheme. Cow 353 was chosen due to the representative changes in titer levels over time following $\mathrm{ZP}$ administration. The results showed significant differences between 1:100 unadsorbed serum and 1:100 adsorbed serum. It was noted that the actual O.D. (titer level) for the adsorbed serum was lower, but continued the same manner as seen in the unadsorbed serum (Fig. 5). These data show that there may have been some $E$. coli background interference $^{[15]}$, but support the cow's ability to produce antibodies to $\mathrm{ZP}$.

The 8 cows in this study experienced different levels of cyclicity throughout the year of ultrasound evaluation. The three control animals had similar cyclic activity with $81 \%$ (cow 716 , cow 748) and $75 \%$ (cow 351) of their $21 \mathrm{~d}$ estrous periods having CL present (Fig. 6). This similarity between controls created a good comparison with respect to the treatment groups.

Cow 441 and cow 226 had similar levels of cyclic activity as compared to control cows, each with $75 \%$ of their $21 \mathrm{~d}$ periods possessing CL (Fig. 6). This indicates that, although these two cows were members of treatment groups (ZP55 and ZP75, respectively); they were able to maintain normal cyclic activity with respect to $\mathrm{CL}$ formation and regression. It is evident that any immune response that may have been generated through administration of DNA encoding ZP to these cows did not affect their ovarian function over time, even though cow 226 had an elevated immune response.

Cow 284, cow 353 and cow 437 showed marked decreases in cyclic activity as compared to control cows, with respective levels of $50 \%, 38 \%$ and $50 \%$ of their $21 \mathrm{~d}$ periods having CL present (Fig. 6). These values indicate that antibodies generated with respect to ZP may have had a detrimental effect on ovarian function and CL formation because cow 353 and cow 437 had elevated immune responses. These findings complement the results of the studies in which ovarian function and viable CL production was disabled due to the administration of a ZP vaccine ${ }^{[3,4,16]}$.

A significant effect of treatment on the left ovarian follicle numbers was evident. The most significant difference was noticed in the Hep55 treatment group, which was statistically lower than the three other treatment groups (Fig. 7). Cow 284 had the lowest number of bilateral follicles, which may indicate that the Hep55 treatment was the most effective inhibitor of follicular production over time.

Zona pellucida proteins have proven effective antigens for immunocontraception in many situations including wildlife population control and pest animal management. The main contraceptive mechanism behind the induction of infertility by $\mathrm{ZP}$ antibodies is known to be through inhibition of sperm binding or penetration of the ZP. In addition to this method, it is speculated that high titers of antibodies or anti-ZP immune complexes may alter ovarian function by interfering with follicle-oocyte communication involved in the regulation of follicular development ${ }^{[3]}$. The study conducted by Miller et al. ${ }^{[4]}$ expanded upon this view by suggesting that if this follicular interference occurred during follicular differentiation, when ZP proteins were synthesized and secreted, ovulation or normal CL development may also be compromised. These findings were noted in the first 2-3 yr post-immunization. 
Similar results were reported by Turner et al. ${ }^{[16]}$, in which active immunization with pZP resulted in a dramatic alteration of ovarian development and function. Burros immunized with ZP proteins had lower fecal estrogen and progesterone metabolites than females that produced foals, suggesting lack of functional $\mathrm{CL}$ to maintain pregnancy. In rabbits immunized with recombinant rZP proteins there was $80 \%$ infertility and antibody binding to $\mathrm{ZP}$ with follicular degeneration ${ }^{[6]}$. It was noted that the ovaries from the immunized rabbits possessed lower numbers of primary, secondary and tertiary follicles when subjected to microscopic analysis.

The typical bovine estrous cycle is $21 \mathrm{~d}(3 \mathrm{wk})$ in length and encompasses two phases that are named for the dominant structures present on the ovary at that time; the follicular phase and the luteal phase ${ }^{[17,18]}$. Cyclicity can be determined by visually recognizing the presence of various sized follicles on the ovary via ultrasonography ${ }^{[19]}$; specifically a large dominant follicle (10 to $12 \mathrm{~mm}$ ) that will differentiate into a CL. As the luteal phase is the longest phase of the estrous cycle, CL may be present on the ovary for 10 to $12 \mathrm{~d}$, but must undergo luteolysis and be destroyed in order for ovulation to occur and a new cycle to begin ${ }^{[18]}$. For the purposes of this study, cyclicity was noted by the appearance and disappearance of CL on each ovary.

These results are in accordance with the previously described research of Turner et al. ${ }^{[2]}$, in which progesterone production was depleted over time in response to $\mathrm{ZP}$ immunization. It is therefore evident that the cows that were given DNA encoded with ZP55 and ZP75 were affected by immunization and decreased their abilities to produce CL.

\section{CONCLUSION}

Through our experiments we have shown that cattle previously injected with ZP DNA vaccines can generate antibody titer levels to ZP proteins. Although not every cow displayed representative titer results, responsive cows will yield similar titer levels that follow a pattern over time. Elevated titer levels to ZP proteins coincided with decreased cyclicity and ovarian function. It is evident that further research is needed in order to fully determine the abilities of cattle to generate adequate antibody titers to inhibit fertilization. Nonetheless, this experiment supports the hypothesis that there is an immunocontraceptive potential for a $\mathrm{ZP}$ vaccine in the cattle industry.

\section{REFERENCES}

1. Govind, C.K. and S.K. Gupta. 2000. Failure of female baboons (Papio anubis) to conceive following immunization with recombinant nonhuman primate zona pellucida glycoprotein-B expressed in Escherichia coli. Vaccine, 18: 29702978.

2. Kaul, R., A. Afzalpurkar and S.K. Gupta, 1997. Expression of bonnet monkey (Macaca radiata) zona pellucida-3 (ZP3) in a prokaryotic system and its immunogenicity. Mol. Reprod. Dev., 47: 140147.

3. Miller, L.A., B.E. Johns and G.J. Killian, 2000. Immunocontraception of white-tailed deer using native and recombinant zona pellucida vaccines. Anim. Reprod. Sci., 63:187-195.

4. Miller, L.A., B.E. Johns and G.J. Killian, 2000. Long-term effects of PZP immunization on reproduction in white-tailed deer. Vaccine, 18: 568-574.

5. Srivastava, N., R. Santhanam, P. Sheela, S. Mukund, S.S. Thakral, B.S. Malik and S.K. Gupta, 2002. Evaluation of the immunocontraceptive potential of Escherichia coli-expressed recombinant dog zp2 and $\mathrm{zp} 3$ in a homologous animal model. Reproduction, 123: 847-857.

6. Kerr, P.J., R.J. Jackson, A.J. Robinson, J. Swan, L. Silvers, N. French, H. Clarke, D.F. Hall and M.K. Holland, 1999. Infertility in female rabbits (Oryctolagus cuniculus) alloimmunized with the rabbit zona pellucida protein $\mathrm{Zpb}$ either as a purified recombinant protein or expressed by recombinant myxoma virus. Biol. Repro., 61: 606613.

7. Dunbar, B.S., N.J. Wardrip and J.L. Hendrick, 1980. Isolation, physiochemical properties and macromolecular composition of zona pellucida from porcine oocytes. Biochemistry, 19: 356-365.

8. Kirkpatrick, J.F., J.W. Turner Jr., I.K. Liu, R. Fayrer-Hosken, 1996. Applications of pig zona pellucida immunocontraception to wildlife fertility control. J. Reprod. Fertil. Suppl., 50: 183-189.

9. Jones, A.L. and W.E. Beal, 2003. Reproductive applications of ultrasound in cattle. Bovine Pract., 37: $1-8$.

10. Fricke, P.M., 2002. Scanning the futureultrasonography as a reproductive management tool for dairy cattle. J. Dairy Sci. ,85: 1918-1926.

11. Butler, S.P, T.K. O'Sickey, S.T. Lord, J. Lubon, F.C. Gwazdauskas and W.H. Velander. 2004. Secretion of recombinant human fibrinogen by the murine mammary gland. Transgenic Res., 13: 437450 . 
12. Braun, R.P., L.A. Babiuk, B.I. Loehr and S. van DrunenLittel-van den Hurk, 1999. Particlemediated DNA immunization of cattle confers long-lasting immunity against bovine herpesvirus1. Virology, 265: 46-56.

13. Mate, K.E., J.M. Buist and J.A. Duckworth, 2003. Expression in Escherichia coli and immunological characterization of three zona pellucida proteins (ZP1, ZP2 and ZP3) from a marsupial, the brushtail possum (Trichosurus vulpecula). Mol. Reprod. Dev., 64: 136-143.

14. Fayrer-Hosken, R.A., H.J. Bertschinger, J.F. Kirkpatrick, D. Grobler, N. Lamberski, G. Honneyman and T. Ulrich, 1999. Contraceptive potential of the porcine zona pellucida vaccine in the african elephant (Loxodonta africana). Theriogenology, 52: 835-846.
15. Deshmukh, N.R. and A.M. Lali, 2005. Adsorptive purification of pDNA on superporous rigid crosslinked cellulose matrix. J. Chromatography B, 818: 5-10.

16. Turner, J.W., I.K. Liu and J.F. Kirkpatrick, 1996. Remotely delivered immunocontraception in freeroaming feral burros (Equus asinus). J. Reprod. Fertil., 107: 31-35.

18. Senger, P.L., 2003. Pathways to Pregnancy and Parturition. 2nd Edn. Current Conceptions, Inc., Pullman, WA.

17. Evans, A.C.O., 2003. Characteristics of Ovarian Follicle Development in Domestic Animals. Reprod. Dom. Anim., 38: 240-246.

19. Pierson, R.A. and O.J. Ginther, 1984. Ultrasonography of the bovine ovary. Theriogenology, 21: 495-504. 